\title{
International Investment Law and ISDS: Mapping Contemporary Latin America
}

\author{
Katia Fach Gómez* \\ University of Zaragoza, Spain \\ katiafachgomez@gmail.com \\ Catharine Titi \\ French National Centre for Scientific Research (CNRS) \& CREDIMI, University of \\ Burgundy, France \\ cathy_titi@hotmail.com
}

Forthcoming in Katia Fach Gómez and Catharine Titi (eds), The Latin American Challenge to the Current System of Investor-State Dispute Settlement, Journal of World Investment \&

Trade: Special Issue 17 (4).

\begin{abstract}
In recent years, the negotiation and conclusion of international investment agreements (IIAs) in Latin America has gone hand-in-hand with a rethinking of investment standards and the elaboration of new IIA models. This is evident, among others, in Brazil's cooperation and facilitation investment agreements (CFIAs), the continuing negotiations on the creation of a regional dispute settlement centre under the aegis of the Union of South American Nations (UNASUR), some recently-released investment policy documents and amendments to national arbitration laws for disputes involving the State. The article highlights such developments emphasising the broad spectrum of local approaches that vary from convergence to divergence in order to interpret Latin American countries' position in the existing investor-State dispute settlement (ISDS) system and reveal the role that the subcontinent can play in the future design of ISDS.
\end{abstract}

\section{Keywords}

Latin America - international investment law - Brazil's cooperation and facilitation investment agreements (CFIAs) - UNASUR Centre for the Settlement of Investment Disputes - national arbitration laws - investor-State dispute settlement - dispute prevention and alternative dispute resolution (ADR)

\section{Introduction}

In recent years, Latin American States have continued their engagement with international investment law. ${ }^{1}$ For instance, over the course of 2014 and 2015, at least 13 international

\footnotetext{
* The authors would like to thank María Luque, Rodrigo Polanco Lazo, Facundo Pérez Aznar, María Gabriela Sarmiento, for their helpful comments on section 5 of this article on developments in relation to various national arbitration laws. Katia Fach Gómez's participation in this Special Issue has been supported by the Alexander von Humboldt Foundation. The author is also member of the Spanish Research Projects DER 2012-36806Subprograma JURI — and e-Procofis S14/3 DGA.
} 
investment agreements (IIAs) were negotiated and signed by countries in the region. Four among them were bilateral investment treaties (BITs). Brazil was the most active treaty negotiator, with six cooperation and facilitation investment agreements (CFIAs) signed, all in 2015, corresponding to about half the concluded IIAs in 2014 and 2015. Colombia and Mexico came next with four IIAs each (of which one for each was a CFIA with Brazil, underlining the Brazilian model's potential influence on the shaping of new trends in Latin America). Half of these agreements are intra-Latin American IIAs. ${ }^{2}$ More recently, in February 2016, the Trans-Pacific Partnership (TPP) Agreement was signed between 12 States, among which were Chile, Mexico and Peru, thus including Latin American parties in what has been one of the most eagerly-awaited mega-regionals. ${ }^{3}$

Latin American countries' negotiation and conclusion of IIAs goes hand-in-hand with a rethinking of investment standards and a specific targeting of the investor-State dispute settlement (ISDS) mechanism, but sometimes also the termination of old generation BITs. ${ }^{4}$ The present article comes only a few years after a few Latin American countries quite vociferously tried to disengage themselves from the existing ISDS system. But a lot has changed in this short period of time, and countries in the region participate in the elaboration of new IIA models, most significantly Brazil, and are actively engaged in the continuing negotiations on the creation of a regional dispute settlement centre under the aegis of the Union of South American Nations (UNASUR). National arbitration laws, and their recent amendments, as well as investment policy documents are equally significant for perceptions of investment dispute settlement in the region. A common denominator amongst several of these developments is a double attempt to endorse arbitration and at the same time to promote alternative dispute resolution (ADR), dispute prevention, and generally investor-State mechanisms less-adversarial than those currently in existence. The preventive approaches fostered by the Colombian National Agency for the Legal Defence of the State ${ }^{5}$ and the Peruvian Coordination and Response System for International Investment Disputes ${ }^{6}$ are only two examples of Latin American States' desire to reduce the number of conflicts in relation to international investment.

The present article highlights some such revealing developments to help better understand Latin American countries' position in the existing ISDS system and reveal the role that the region can play in the shaping of new investment standards and notably the design of ISDS. More particularly, the article will focus on recent developments in Latin America that have been driving reform of IIAs and especially ISDS, highlighting the presence of converging lines and at the same time the absence of an overall unique regional approach to investment dispute settlement. Wishing to perceive Latin America as one 'continent' where ISDS is concerned fails to capture the complexity and multiplicity of regional approaches to the

\footnotetext{
${ }^{1}$ For an analysis of some approaches to foreign investment in the region during the period 2004-2012, see María José Luque Macías 'Current Approaches to the International Investment Regime in South America' in Christoph Herrmann, Markus Krajewski and Jörg Philipp Terhechte (eds), European Yearbook of International Economic Law (Springer 2013) 285.

${ }^{2}$ See <http://investmentpolicyhub.unctad.org/IIA> accessed 1 March 2016.

${ }^{3}$ The other parties are: Australia, Brunei, Canada, Japan, Malaysia, New Zealand, Singapore, United States, and Vietnam. On TPP, see < https://ustr.gov/tpp/> accessed 1 March 2016.

${ }^{4}$ The year 2014, for example, saw the termination of the Argentina-Bolivia BIT and 2015 the termination of the Argentina-Indonesia BIT. See <http://investmentpolicyhub.unctad.org/IIA/CountryBits/8> accessed 1 March 2016.

5 Agencia nacional de defensa jurídica del <http://www.defensajuridica.gov.co/Paginas/Default.aspx $>$ accessed 1 March 2016.

6 Sistema de Coordinación y Respuesta del Estado en Controversias Internacionales de Inversión - SICRECI <https://www.mef.gob.pe/index.php?option=com_content\&view=article\&id=3970\&Itemid=100906\&lang=es > accessed 1 March 2016.
} 
investor-State dispute settlement mechanism. ${ }^{7}$ The article will commence with the negotiations on UNASUR's Centre for the Settlement of Investment Disputes, and it will continue with Brazil's new IIA model of dispute prevention. Two further sections will explore respectively the recommendations of Ecuador's Audit Commission on Investment Treaties and the Southern Observatory on Investment and Transnational Corporations, and developments in relation to national laws in Latin America.

\section{A New Dispute Resolution Mechanism in the Offing: The UNASUR Centre for the Settlement of Investment Disputes}

Recent years have witnessed noteworthy developments in relation to the creation of the proposed Centre for the Settlement of Investment Disputes (Centro de solución de controversias en materia de inversiones) negotiated under the auspices of UNASUR. ${ }^{8}$ This proposed Centre is at the moment the most advanced Latin American initiative to create a regional dispute settlement institution endowed with procedural rules that have significant differences with the current mainstream ISDS system. According to their creators' intentions, this dispute settlement centre might overshadow the hegemony of the International Centre for Settlement of Investment Disputes (ICSID). ${ }^{9}$

The negotiation process for the Centre's establishment can be summarised as follows: the 2008 Decision on the Guidelines for a UNASUR Action Plan stressed the importance of creating a mechanism for the resolution of investment disputes, of a voluntary character and complementary to the existing ones. ${ }^{10}$ The 2009 Third Extraordinary Meeting of the Council of UNASUR's Foreign Affairs Ministers in Quito restated its intention of developing a mechanism for the settlement of investment disputes. ${ }^{11}$ In June 2009, at the 39th Session of the General Assembly of the Organization of American States, Ecuador's Foreign Minister publicly supported the creation of a UNASUR Centre on this issue. The 2010 Declaration of the UNASUR Council of Heads of State and Government, issued during its IV Ordinary Session in Guyana, urged the prompt convening of the UNASUR High Level Experts Working Group on the Settlement of Investment Disputes. ${ }^{12}$ At that moment, Ecuador presented a written proposal consisting of three documents (a set of rules for an arbitration centre, a code of conduct for UNASUR arbitrators and mediators, and a counselling centre for

\footnotetext{
7 See generally Catharine Titi, 'Investment Arbitration in Latin America: The Uncertain Veracity of Preconceived Ideas', (2014) 30 (2) Arbitration International 357.

${ }^{8}$ María Ángeles Cano Linares "The Union of South American Nations: An Emerging Regional Organization" in Marco Odello and Francesco Seatzu (eds), Latin America and Caribbean International Law (Asser Press 2015) 43.

${ }^{9}$ For a proposal for the steady development of additional alternative arbitration fora in Latin America within ALBA-TCP (Alianza Bolivariana para los Pueblos de Nuestra América - Tratado de Comercio de los Pueblos) and MERCOSUR (Mercado Común del Sur), see Hildegard Rondón de Sansó 'Arbitraje Internacional de Inversión : críticas y alternativas' <http://www.correodelorinoco.gob.ve/opinion-libre/arbitraje-internacionalinversion-criticas-y-alternativas-opinion/> accessed 1 March 2016. See further Titi (n 7) 380.

10 'Decisión sobre el plan de acción de <http://www.menpet.gob.ve/repositorio/imagenes/file/Documentos/unasur/PlandeacciondeUnasur.pdf> accessed 1 March 2016

11 'Listo el texto de la declaración presidencial de Quito' $<$ http://presidencia.informatica.gob.ec/index.php?option=com_content\&view=article\&id=4733:listo-el-texto-dela-declaracion-presidencial-de-quito\&catid=2:politica\&Itemid=43> accessed 1 March 2016.

12 'Declaración del Consejo de Jefas y Jefes de Estado y de Gobierno de la Unión de Naciones Suramericanas (UNASUR)' $<$ http://sedici.unlp.edu.ar/bitstream/handle/10915/44524/UNASUR__Declaraci\%C3\%B3n_del_Consejo_de_Jefes_y_Jefas_de_Estado_y_de_Gobierno_de_la_Uni\%C3\%B3n_de_N aciones_Suramericanas_UNASUR__12_p._.pdf?sequence=64> accessed 1 March 2016.
} 
settling investment disputes), whose content has been analysed by various authors. ${ }^{13}$ In subsequent years, the working group met on several occasions. ${ }^{14}$ After its IV meeting held in Lima in November 2012, the working group presented a Draft Constitutive Agreement of the Investment-Related Dispute Settlement Centre of the UNASUR. ${ }^{15}$

Subsequent negotiations and meetings of the working group led it to present a more elaborated 2014 Draft Constitutive Agreement of the Centre for the Settlement of Investment Disputes of UNASUR ${ }^{16}$. Some of the main characteristics of this 41 -article draft, which certainly deserves a detailed scholarly analysis, ${ }^{17}$ are the following: The Centre has international legal personality and some privileges and immunities (Articles 4 and 11); it is composed of a Board of Directors and a Secretariat (Article 7); the Centre offers mechanisms of facilitation, conciliation and arbitration (Article 13); it has jurisdiction over both StateState disputes and investor-State disputes (as long as both or one party to the dispute is a UNASUR member State or has the nationality of a UNASUR member State, Article 5); in investor-State disputes, the State may require the exhaustion of local administrative or judicial remedies as a precondition to submitting a dispute to conciliation or arbitration to the UNASUR Centre (Article 5.11); the arbitral tribunal is composed of a unique arbitrator or of an odd number of arbitrators who are in principle appointed as agreed by the parties (Article 18.5); numerous aspects of the arbitration procedure will by governed by an additional set of rules created by the Centre - the Mechanisms Rule (Article 20); parties may submit requests for interpretation, rectification and issuance of additional arbitral awards (Article 23); the award shall be final and binding upon both parties to the dispute and shall become enforceable (Article 33). The 2014 Draft has excluded various proposals contained in earlier drafts, which had raised some eyebrows amongst lawyers and academics. The rejected proposals included that the Centre's services would not be made available to non-UNASUR States and investors for a period of years; the Centre would not have jurisdiction over disputes concerning health, education, taxation, energy, the environment and others unless expressly agreed otherwise; or over disputes concerning the internal law of a UNASUR member State; arbitrators would need to complete the public exams established by each UNASUR State. ${ }^{18}$

The latest meeting of the UNASUR working group took place in Montevideo in January 2016 and at the time of writing a further meeting is scheduled in the same place for

\footnotetext{
${ }^{13}$ Silvia Karina Fiezzoni, 'UNASUR Arbitration Centre: The Present Situation and the Principal Characteristics of Ecuador's Proposal' <https://www.iisd.org/itn/2012/01/12/unasur/>; Christian Leathley, 'What Will the Recent Entry into Force of the UNASUR Treaty Mean for Investment Arbitration in South America?' <http://kluwerarbitrationblog.com/2011/04/13/unasur-treaty-and-investment-arbitration-in-south-america/> both accessed 1 March 2016.

${ }^{14}$ María Gabriela Sarmiento, 'The Centre for the Settlement of Investment Disputes of the UNASUR. Historical Background and Current Status of the Centre' <http://papers.ssrn.com/sol3/papers.cfm?abstract_id=2703587> accessed 1 March 2016.

15 An English unofficial translation of the text can be found in María Gabriela Sarmiento, 'The 2012 Draft Constitutive Agreement of the Centre for the Settlement of Investment Disputes of the UNASUR' <http://papers.ssrn.com/sol3/papers.cfm?abstract_id=2698574> accessed 1 March 2016

${ }^{16}$ An English unofficial translation can be found in María Gabriela Sarmiento, 'The 2014 Draft Constitutive Agreement of the Centre for the Settlement of Investment Disputes of the UNASUR' <http://ssrn.com/abstract=2703651> accessed 1 March 2016.

17 See in general, this Special Issue. And especially, José Manuel Álvarez Zárate and Rebecca Pendleton, 'Democracy and the International Rule of Law in Investment Arbitration: Latin American Advances in Arbitrator Appointment and Disqualification' in Katia Fach Gómez and Catharine Titi (eds), The Latin American Challenge to the Current System of Investor-State Dispute Settlement, Journal of World Investment \& Trade: Special Issue 17 (4), 2016 (forthcoming); and María Gabriela Sarmiento 'The UNASUR Centre for the Settlement of Investment Disputes and Venezuela. Will both ever see the light at the end of the tunnel?' Katia Fach Gómez and Catharine Titi (eds), The Latin American Challenge to the Current System of Investor-State Dispute Settlement, Journal of World Investment \& Trade: Special Issue 17 (4), 2016 (forthcoming).

${ }^{18}$ Leathley (n 13).
} 
29-31 March 2016. ${ }^{19}$ At first glance, it seems very positive that the group has reached a consensus on approximately 80 per cent of the UNASUR Centre's constitutive agreement. ${ }^{20}$ However, one fact cannot be underestimated: Article 12 of the UNASUR Constitutive Treaty requires consensus among its States in order for any UNASUR legislative measure to be approved, ${ }^{21}$ and in this particular legislative initiative a consensus still needs to be reached with respect to multiple important aspects. UNASUR member States hold different stances on issues such as the definition of 'national of another member State' (Articles 3.2 and 5.14); the definition of 'dispute' (Article 3.4); the appropriateness of using the most-favourable-nation clause regarding the State's consent to the Centre's jurisdiction (Article 5.8); arbitrators' competencies and the creation of a candidates' list for ad hoc arbitrations (Article 34.3, 34.3.bis, 34.3.ter and 34.3.quater); arbitral awards (content and public nature, Article 22); deadline to comply with the arbitral award before beginning recognition and enforcement procedures (Article 33.8); body in charge of reviewing the petition for annulment of the arbitral award (either a Permanent Court or an ad hoc Committee, Article 30); and the need to include an appeals mechanism and its possible configuration - Permanent Court or an ad hoc Committee (Article 31). There are also two additional pending issues of a more political nature (enty-into-force, Article 35, and reservations, Article 40), which will probably need to be discussed with the UNASUR Council of Ministers of Foreign Affairs. ${ }^{22}$ Finally, the headquarters of the Centre, including its Secretariat, also need to be agreed upon (Article 10).

It is clear that 2016 will be a crucial year for the future of the UNASUR Centre for the Settlement of Investment Disputes. Although some UNASUR states are hopeful in terms of a successful completion of the negotiation process ${ }^{23}$, it remains to be seen whether the future meetings of the working group will bring about political and legal agreement on the troubled aspects of the Constitutive Agreement. It is also unclear whether the Venezuelan assumption of the UNASUR Pro-tempore presidency in 2016 will somehow speed up or slow down consensus. ${ }^{24}$ At the same time, the Centre's prospective existence may generate scepticism, as its operation might scorn international standards in favour of regional ones and lead to increased instability in the region and to investment and welfare decrease. Negative

\footnotetext{
${ }^{19}$ Resolución Ministerial peruana $\mathrm{n}^{\mathrm{a}}$ 102-2016-PRODUCE 'Autorizan viaje de asesor a Uruguay, en comisión de servicios' See http://www.asesorempresarial.com/web/pdf/16032016.pdf> accessed 16 March 2016.

20 'UNASUR Close to Forming Investor Dispute Center', TeleSUR, 19 January 2016 <http://www.telesurtv.net/english/news/UNASUR-Close-to-Forming-Investor-Dispute-Center-201601190036.html> accessed 1 March 2016.

21 South American of Union Nations Constitutive <http://studentorgs.law.smu.edu/getattachment/International-Law-Review-Association/Resources/LBRAArchive/15-2/SMB213.pdf.aspx> accessed 1 March 2016.

22 'Acta de la (sic) decima tercera reunión presencial del grupo de trabajo de expertos de alto nivel sobre solución de controversias en materia de inversiones de UNASUR' $<$ https://repo.unasursg.org/alfresco/service/unasursg/documents/content/ACTA_DE_LA_DECIMA_TERCERA _REUNION_PRESENCIAL_DEL_GRUPO_DE_TRABAJO_DE_EXPERTOS_DE_ALTO_NIVEL_SOBRE_ SOLUCION_DE_CONTROVERSIAS_EN_MATERIA_DE_INVERSIONES_DE_UNASUR.pdf?noderef $=388$ 3225f-6ec1-48bd-8dc9-72e6ed7dbfc4> accessed 1 March 2016.

23 The Peruvian Ministry of Foreign Affairs stated in March 2016: 'It is necessary to ensure the Peruvian participation in the meeting for the purpose of enabling an appropriate follow up aimed at the successful completion of the negotiation process of the Constitutive Agreement of the Investment-Related Dispute Settlement Centre of the UNASUR' (n 19).

24 'Venezuela asumirá presidencia pro témpore de Unasur en abril' $<$ http://www.elespectador.com/noticias/elmundo/venezuela-asumira-presidencia-pro-tempore-de-unasur-abrarticulo-616106> accessed 1 March 2016. Diana Tussie 'Presidential diplomacy in UNASUR: coming together for crisis management or marking turfs' <https://www.academia.edu/15050987/Presidential_diplomacy_in_UNASUR_coming_together_for_crisis_man agement_or_marking_turfs> accessed 1 March 2016.
} 
reactions to the Centre have also been noted amongst (Latin American) scholars, ${ }^{25}$ underlying the existing divergence in Latin American approaches. Some of these concerns are understandable, but it is also possible that the creation of the UNASUR Centre could increase legitimacy of ISDS among the system's currently most reluctant participants. In addition, the bitter lessons learnt from the current ISDS system may have been internalised by the drafters of the UNASUR Centre, resulting in the implementation of the procedural and substantive novelties demanded by civil society, non-governmental organisations (NGOs) and developing States. Whenever it happens, its launch may constitute the beginning of a new era for investment arbitration in the Latin South American region.

\section{Endorsement of an Innovative Dispute Prevention Model: Brazilian Cooperation and Facilitation Investment Agreements}

One of the most spectacular developments in the region has been Brazil's elaboration of a model cooperation and facilitation investment agreement and its conclusion of six CFIAs in 2015. This is a noteworthy breakthrough, given both Brazil's economic weight (the South American State has until recently been the fifth biggest economy word-wide ${ }^{26}$ and it is the first economy in Latin America ${ }^{27}$ ) and Brazil's so-far reluctance to embrace the international investment law system. ${ }^{28}$ The country's earlier BITs signed in the 1990s but never ratified were deemed to be incompatible with the Brazilian Constitution due to their provisions on expropriation and ISDS. ${ }^{29}$ Brazil's new model aims to remove these internal legal barriers to ratification, and it 'seeks a balanced outcome combining the promotion of an attractive environment for investors while preserving space for public policies' ${ }^{30}$ The model is no longer focused on investment protection and dispute settlement - indeed ISDS is not possible on the basis of the CFIAs - but on investment promotion and dispute prevention, objectives which are expressly cited in the treaties. ${ }^{31}$ Dispute prevention, in particular, involves as a rule of thumb 'extensive planning in order to reduce the number of conflicts that escalate or crystallize into formal disputes' ${ }^{32}$ In other words, it requires the creation of specific institutional mechanisms. ${ }^{33}$ The CFIA model, at least in its original form, reposed on a threepillar structure. ${ }^{34}$ Very recently, this structure seems to have been partially abandoned, but the content of the model has been retained. For simplification purposes, the explanation that follows will refer to the original structure. Although only one of the pillars explicitly relates to

\footnotetext{
${ }^{25}$ María Gabriela Sarmiento 'The UNASUR Centre for the Settlement of Investment Disputes and Venezuela. Will Both Ever See the Light at the End of the Tunnel?' Katia Fach Gómez and Catharine Titi (eds), The Latin American Challenge to the Current System of Investor-State Dispute Settlement, Journal of World Investment \& Trade: Special Issue 17 (4), 2016 (forthcoming); María José Luque Macías 'Inter-State Investment Dispute Settlement in Latin America: Is There Space for Transparency?' in Katia Fach Gómez and Catharine Titi (eds), The Latin American Challenge to the Current System of Investor-State Dispute Settlement, Journal of World Investment \& Trade: Special Issue 17 (4), 2016 (forthcoming).

${ }^{26}$ UNCTAD, World Investment Report 2014 (UN 2014) 4, figure I.3, see also 28, figure I.28.

${ }^{27}$ UNCTAD, World Investment Report 2015 (UN 2015) 5, figure I.3.

${ }^{28}$ See in general Daniel de Andrade Levy, Ana Gerdau de Borja and Adriana Noemi Pucci (eds), Investment Protection in Brazil (Kluwer Law International 2014).

29 Catharine Titi, 'International Investment Law and the Protection of Foreign Investment in Brazil', Transnational Dispute Management, advance publication on 13 July 2015, forthcoming in Transnational Dispute Management Special Issue on Latin America (eds Ignacio Torterola and Quinn Smith) 4, 6.

30 Daniel Godinho, 'Statement', UNCTAD World Investment Forum (16 October 2014), <http://unctadworldinvestmentforum.org/wp-content/uploads/2014/10/Godinho.pdf> accessed 1 March 2016.

${ }^{31}$ E.g. Article 1 of the Brazil-Mexico CFIA and Article 2 of the Brazil-Chile CFIA.

${ }^{32}$ UNCTAD, Investor-State Disputes: Prevention and Alternatives to Arbitration (UN 2010) xiv.

33 Ibid.

${ }^{34}$ On the three pillars of Brazilian CFIAs, see generally Titi (n 29) 9 et seq.
} 
dispute prevention, in reality the topic is addressed in all three of them more or less directly. The first pillar consists in improved institutional governance, which is to be achieved through the establishment of a joint committee and of so-called 'focal points' (ombudsmen). The joint committee will be 'responsible for sharing opportunities for the expansion of mutual investment, monitoring the implementation of the Agreement, preventing disputes and solving possible disagreements in an amicable manner' ${ }^{35}$. The focal points will serve as communication channels between foreign investors and the host State, in order to propose inter alia improvements to the business environment, ${ }^{36}$ prevent disputes and facilitate their resolution. ${ }^{37}$ The second pillar concerns the development of specific working 'agendas' that will create an 'attractive business environment', such as cooperation on business visas and environmental regulation. ${ }^{38}$ The third pillar comprises mechanisms for risk mitigation and dispute prevention. It also includes the treaty's substantive standards of investment protection. This last pillar seeks to prevent disputes through 'dialogue and bilateral consultation, prior to the initiation of State-State arbitration procedures' ${ }^{39}$. In this respect, the focal points are tasked with coordinating between them and with the joint committee to prevent and resolve eventual disputes between the parties; steps to be taken prior to State-State dispute settlement proceedings are consultations and negotiations and an examination by the joint committee. ${ }^{40}$

Brazil's wariness with ISDS reflects concerns in a few neighbouring countries, such as those that incited Ecuador to propose the creation of UNASUR's regional dispute resolution centre. But in contrast with the latter which started as a reaction to the current system, the elaboration of Brazil's model comes as an apparent attempt to embrace - however incompletely - international investment law. Brazil's obligations on the basis of CFIAs may turn out be 'softer' than ISDS-backed commitments assumed through other Latin American IIAs, but they are buttressed by policy arguments presented by the Brazilian Government. Reportedly, Government consultations with local businesses revealed no appetite for ISDS and drove home the importance of other priorities, such as cooperation between the parties on business visas. ${ }^{41}$ It is significant that over the course of last year Brazil concluded three intraLatin American CFIAs with Chile, Colombia and Mexico, ${ }^{42}$ countries well-embedded in the current investment law and ISDS system. Having said that, a paradox should no less go unnoticed: as a UNASUR member State Brazil too participates in the negotiations on the regional Centre for the Settlement of Investment Disputes.

\section{New Sovereigntist Policies and Strategies: Recommendations of Ecuador's Audit Commission on Investment Treaties and the Southern Observatory on Investment and Transnational Corporations}

\footnotetext{
${ }^{35}$ Godinho (n 30).

${ }^{36}$ Renato Souza, 'Cooperation and Facilitation Investment Agreement - CFI', Presentation, UNCTAD Expert Meeting on The Transformation of the International Investment Agreement Regime (25 February 2015) <http://unctad-worldinvestmentforum.org/wp-content/uploads/2015/03/Brazil_side-event-Wednesday_modelagreements.pdf> accessed 1 March 2016.

${ }^{37}$ E.g. respective Article 5(4) of the Brazil-Mozambique CFIA and the Brazil-Angola CFIA.

${ }^{38}$ E.g. see respective Article 8 of the Brazil-Mozambique CFIA and the Brazil-Angola CFIA.

${ }^{39}$ Emphasis added.

40 Respective Article 15 of the Brazil-Mozambique CFIA and the Brazil-Angola CFIA (2015). For some considerations on inter-State arbitration on the basis of Brazil's CFIAs, see María José Luque Macías, 'InterState Investment Dispute Settlement in Latin America: Is There Space for Transparency?' in Katia Fach Gómez and Catharine Titi (eds), The Latin American Challenge to the Current System of Investor-State Dispute Settlement, Journal of World Investment \& Trade: Special Issue 17 (4), 2016 (forthcoming).

${ }^{41}$ Titi (n 29) 12.

${ }^{42}$ See <http://investmentpolicyhub.unctad.org/IIA> accessed 1 March 2016.
} 
Initiatives such as the creation of the Ecuadorian Commission for a Comprehensive Audit of Investment Protection Treaties and of the International Investment Arbitration System (Comisión para la Auditoría Integral Ciudadana de los Tratados de Protección Recíproca de Inversiones y del Sistema de Arbitraje Internacional en Materia de Inversiones - CAITISA), and the Southern Observatory on Investment and Transnational Corporations (Observatorio del Sur sobre inversiones y transnacionales), ${ }^{43}$ demonstrate that specific Latin American States are particularly concerned about showing both the buttressing axes of their new sovereigntist investment policies as well as the support their policies receive by the national communities. This is an additional reason why Latin America cannot be seen as a homogeneous region, given the broad political spectrum covered by the different governments ruling this sub-continent and their dissimilar stance regarding international investment.

In 2013, the Ecuadorian Government created a Commission for a Comprehensive Audit of Investment Protection Treaties and of the International Investment Arbitration System (CAITISA). ${ }^{44}$ The Commission is composed of twelve government officials, investment lawyers and scholars, and civil society representatives. These members, most of them Latin American but not Ecuadorian, were tasked with assessing the legality and legitimacy of Ecuador's BITs and the characteristics of the cases filed against the country. CAITISA was also expected to determine whether the BITs have truly helped to attract foreign direct investment (FDI) in Ecuador and contributed to the quality of investment in terms of national development. Additionally, CAITISA was entrusted with proposing legal and policy alternatives to traditional BITs and ISDS. ${ }^{45}$

CAITISA has presented the results of its work in three documents of particularly questionable objectivity (Comparative Analysis of substantive clauses contained in Ecuadorian BITs, Conclusion, and Final Recommendations), which were leaked by an Ecuadorian newspaper at the end of January $2016 .{ }^{46}$ Some of CAITISA's main conclusions and recommendations are the following: BITs have weakened the sovereign powers of Ecuador, and contributed to minimising the responsibility of multinational enterprises; foreign direct investments in Ecuador have hampered the country's development; the obligations contained in the BITs violate several Ecuadorian constitutional mandates as well as Ecuador's international human rights' commitments; Ecuador should continue with the process of denouncing BITs, renegotiate international contracts and create new and more balanced regulatory instruments between the State and investors.

Additionally, investor claims should be resolved by Ecuadorian national courts and, if arbitration cannot be avoided, it is necessary that the process of selection and challenge of arbitrators be based on radically new principles, since the current system reveals many arbitrators' clear tendency to favour investor interests. This is why investment arbitrators should not benefit from any type of immunity. CAITISA also indicates that a new national system of recognition and enforcement of international awards rendered against Ecuador should be created, including a constitutionality and legality control. CAITISA additionally

\footnotetext{
${ }^{43}$ Also named 'Observatorio Sur de Empresas Transnacionales' in some sources. 'CELAC anuncia la creación de Observatorio Sur de Empresas Transnacionales` <http://www.celag.org/celac-anuncia-la-creacion-deobservatorio-sur-de-empresas-transnacionales/> accessed 1 March 2016.

${ }^{44}$ Comisión para la Auditoría Integral Ciudadana de los Tratados de Protección Recíproca de Inversiones y del Sistema de Arbitraje Internacional en Materia de Inversiones (CAITISA) <http://www.caitisa.org/> accessed 1 March 2016.

45 Caitisa <http://unctad-worldinvestmentforum.org/wp-content/uploads/2015/03/CAITISA.pdf> accessed 1 March 2016; Andrés Arauz G. (2015) 'Ecuador's Experience with Intenraitnal Investment Arbitration' 5 Investment Policy Brief.

${ }^{46}$ 'Diagonal hace público los resultados de la auditoría sobre tratados de inversión en Ecuador' <https://www.diagonalperiodico.net/global/29135-diagonal-hace-publicos-resultados-la-auditoria-sobre-tbi-delecuador.html> accessed 1 March 2016.
} 
supports the creation of a permanent international or regional arbitration tribunal, as well as an International Observatory on Investment and Transnational Corporations. ${ }^{47}$

After pointing out the substantial similarities between Ecuadorians BITs, the Free Trade Agreement of the Americas, and the 2012 Free Trade Agreement between Colombia and Peru and the European Union (negotiations for Ecuador's accession to the latter were concluded in 2014), ${ }^{48}$ CAITISA considers that this latest text may perniciously encourage capital flight and create a crisis in Ecuador's balance of payments. This manifest stance against the recent change of direction taken by the Correa Government regarding international investments is reportedly one of the reasons that prompted the resignation of CAITISA's former president in $2014 .{ }^{49}$

At about the time CAITISA was created, the second Ministerial Conference of States Affected by Transnational Interests ${ }^{50}$ culminated in September 2014 in the Caracas Declaration, which launched another Ecuadorian initiative: ${ }^{51}$ the Southern Observatory on Investment and Transnational Corporations. ${ }^{52}$ This Observatory was first discussed in an ALBA-TCP meeting in 2013 in Guayaquil ${ }^{53}$, and it was an essential novelty contained in the Declaration issued by the first Ministerial Conference of Latin American States Affected by Transnational Interests. ${ }^{54}$ The Southern Observatory is an ambitious intergovernmental initiative aimed to promote strategic thinking for the defence of the interests of States with investment experts and public officials providing technical and legal advice on investment for the South. ${ }^{55}$ It is further intended to promote the creation of mechanisms for the coordination and exchange of information and knowledge between, on the one hand, the Observatory and, on the other hand, institutions, think tanks and civil society in relation to international investment rules and dispute resolution. ${ }^{56}$ In this regard, the project has been valued by legal scholarship as an initiative to achieve greater transparency in ISDS $^{57}$. The Caracas Declaration further expresses its support for the elaboration of a United Nations' (UN) legally

\footnotetext{
${ }^{47}$ See below. This last issue has also been recently analysed by the Latin American and Caribbean Economic System, 'Efectos económicos, legales y ambientales de la operación de las empresas transnacionales en América Latina y el Caribe' <http://www10.iadb.org/intal/intalcdi/PE/2014/14873.pdf> accessed 1 March 2016.

48 'EU and Ecuador conclude negotiations for trade and development agreement' <http://europa.eu/rapid/pressrelease IP-14-845 en.htm> accessed 1 March 2016.

49 'Los resultados de la auditoría sobre tratados de inversión en Ecuador' <http://omal.info/IMG/article_PDF/Los-resultados-de-la-auditora_a7467.pdf> accessed 1 March 2016.

50 Various non-Latin American States (i.e., Russia, India, Qatar, Indonesia, Malaysia, Angola, Namibia, Zimbabwe) also participated in this meeting as observers. This may have been the reason why the reference to Latin America in the title of the II Ministerial Conference was eventually deleted.

${ }^{51}$ See <http://www.cancilleria.gob.ec/southern-states-reaffirmed-their-support-on-the-transnational-observatorycenter/> accessed 1 March 2016.

52 See <http://www.cancilleria.gob.ec/southern-states-organize-observatory-on-transnational-investment/> accessed 1 March 2016. This should not be confused with other Caracas declarations, such as the 1954 Caracas Declaration of the Organization of American States or the 2011 Caracas Declaration Creating the Community of Latin American and Caribbean States (CELAC). The original text of the Declaration is available here: $<$ http ://www.albamovimientos.org/2014/09/declaracion-ii-conferencia-ministerial-de-estados-afectados-porintereses-transnacionales/> accessed 1 March 2016.

53 See <http://albatcp.cubaminrex.cu/page/xii-cumbre-guayaquil-ecuador-30-de-julio-de-2013> accessed 1 March 2016.

54 This Declaration was only signed by Latin American States (Bolivia, Cuba, Ecuador, Nicaragua, the Dominican Republic, Saint Vincent and the Grenadines, and Venezuela) <http://www.cancilleria.gob.ec/wpcontent/uploads/2013/04/22abr_declaracion_transnacionales_esp.pdf> accessed 1 March 2016.

55 Ibid.

${ }^{56}$ Ibid.

57 María José Luque Macías, 'Reliance on Alternative Methods for Investment Protection through National Laws, Investment Contracts, and Regional Institutions in Latin America', in Steffen Hindelang and Markus Krajewski (editors), Shifting Paradigms in International Investment Law. More Balanced, Less Isolated, Increasingly Diversified (OUP 2016) 291.
} 
binding human rights instrument to regulate the activities of transnational corporations and other business enterprises. ${ }^{58}$ It further contains a jumbled laundry list of unrelated elements (e.g. recitals welcoming Ecuador's launch of CAITISA, and praise to the Venezuelan Government for 'the organizational arrangements and hospitality' in relation to the Ministerial).While the Declaration articulates some laudable objectives (e.g. promotion of equity and justice), it emphasises the importance of State sovereignty. In addition, the tone of some statements pronounced by high-level political representatives of the participating Latin American countries may cast doubts about the future of the Observatory as a reliable institution beyond the Latin American region. During the second Ministerial Conference, Ricardo Patiño, Ecuadorian Minister of Foreign Affairs, declared that 'some transnational corporations and other government powers have manipulated the arbitration systems, thus discovering (sic) the truth about the double standards and conflict of interest. An entire industry of arbitration has been generated, dominated by a small and compact group of law firms and specialised arbitrators of northern countries ... If countries are disunited, the conditions are established by transnational enterprises. But if our countries are united, we will be the ones to set the conditions. ${ }^{59}$

\section{Developments in Relation to Different National Arbitration Laws in Latin America}

Recent years have also witnessed significant developments concerning national legislation in Latin America on commercial and investment arbitration. Both are important waymarks for the role that Latin America can play for the future of ISDS, since they reveal tendencies with respect to arbitration that may involve the State, once again highlighting the differences between countries in the region. Various Latin American countries revamped their national rules on commercial arbitration. This is the case of Argentina, whose new National Civil and Commercial Code (Código civil y comercial de la nación) ${ }^{60}$ entered into force on 1 August 2015. Chapter 29 of the Code (Articles 1649-1665) deals with commercial arbitration. ${ }^{61}$ Some of these new provisions have been questioned, especially from an international lawyer's perspective. For instance, the Code declares that private law issues, in which public policy is at stake, are not arbitrable (Article 1649); it seems that in some cases a State court may review the substance underlying interim relief granted by an arbitrator (Article 1655.2); and a provision dealing with the judicial review of awards - 'in the arbitration contract it is not possible to waive the judicial challenge of a final award which is contrary to the legal system' - raises many interpretative problems (Article 1656.3) ${ }^{62}$ However, the provisions of the Code relating to arbitration contracts are explicitly not applicable to disputes involving the federal or local States (Article 1651). Brazil also amended its 1996 Arbitration Act (Lei de arbitragem) on 26 May 2015. ${ }^{63}$ The new version of this Act has aroused the interest of

\footnotetext{
58 The instrument is legally possible after UN Regulation 26/9 on the elaboration of an international legally binding instrument on transnational corporations and other business enterprises with respect to human rights, A/HRC/RES/26/9 (14 July 2014).

${ }^{59}$ Verónica Villaruel 'Estados del Sur ponen en marcha Observatorio sobre Inversiones Transnacionales ‘ (2014) $10 \quad$ Revista $\quad$ Diplomacia ciudadana 18 <https://issuu.com/cancilleriaec/docs/revista_diplomacia_ciudadana_d_cim> accessed 1 March 2016.

${ }^{60}$ Código Civil y Comercial de la Nación, Boletin Oficial de la República Argentina, 8 October 2014, <http://www.nuevocodigocivil.com/wp-content/uploads/2015/texto-boletin-oficial.pdf> accessed 1 March 2016.

${ }^{61}$ Fernando Aguilar ‘Arbitraje y el nuevo Código Civil y Comercial argentino' (2015) 918 Revista de Notariado.

${ }^{62}$ Emmanuel E. Kaufman and Ezequiel H. Vetulli, 'The New Argentinian Legislation on Arbitration: Shift into First Gear or Reverse?' <http://kluwerarbitrationblog.com/2016/01/19/the-new-argentinian-legislation-onarbitration-shift-into-first-gear-or-reverse/> accessed 1 March 2016.

63 Lei de arbitragem, $\mathrm{N}^{\mathrm{o}}$ 13.129, 26 May 2015 <http://www.planalto.gov.br/ccivil_03/_Ato20152018/2015/Lei/L13129.htm> accessed 1 March 2016.
} 
practitioners and scholars, who point out that this amendment gives legal status to various practices that had been consolidated in the Brazilian arbitration milieu, and in general terms extol the positive attitude of the current Brazilian legislator and national jurisprudence regarding ADR mechanisms. ${ }^{64}$ However, the specific vetoes exercised by the Brazilian President in-office before sanctioning the Act have been criticised. ${ }^{65}$ Likewise, Peru amended its 2008 Arbitration Act (Ley de abitraje) on 26 September 2015. ${ }^{66}$

In 2014 and 2015, there have also been various noteworthy developments in national Latin American laws regarding investments and investment arbitration. On 4 April 2014, Bolivia passed its Act No. 516 on the promotion of investments (Ley de promoción de inversiones), ${ }^{67}$ abrogating the 1990 Act No 1182 on investments and anticipating the elaboration of a new Conciliation and Arbitration Act (see below). On 25 June 2015, Chile passed its Act No. 20848 establishing the framework for foreign direct investment in Chile (Ley que establece marco para la inversión extranjera directa en Chile y crea la institucionalidad respectiva),${ }^{68}$ which does not address ISDS, and is focused on specifying the administrative details for foreign investment in Chile as well as fostering it. ${ }^{69}$ This is a major change in the Chilean framework for FDI, as the new Act replaces the so-called DL 600 - the foreign investment statute in force in Chile since 1974. ${ }^{70}$ The new Act No. 20848 eliminates several tax benefits for foreign investors, and introduces the recognition of a 'foreign investor' status through the issuance of a certificate (Article 4) by the novel Foreign Investment Promotion Agency - that replaces the Foreign Investment Committee.

On the same day but with a very different ratio legis, Bolivia passed a new International Conciliation and Arbitration Act (Ley 708 de conciliación y arbitraje internacional) $^{71}$ abrogating the 1997 Bolivian Arbitration and Conciliation Act (Ley de arbitraje y conciliación). This new Act, composed of 135 articles, is said to be the result of a consensus reached with important sectors of the Bolivian society. ${ }^{72}$ Besides offering a more complete regulation on conciliation and commercial arbitration, the 2015 Act sets in place a special conciliation and arbitration regime dealing with investment disputes where the Bolivian State is involved as defendant in disputes brought either by Bolivian investments, by

\footnotetext{
${ }^{64}$ Alejandro López Ortiz and Gustavo Fernandes, 'A Year of Legal Developments for International Arbitration in Latin America’ <http://kluwerarbitrationblog.com/2016/01/11/a-year-of-legal-developments-for-internationalarbitration-in-latin-

america/?utm_source=feedburner\&utm_medium=email\&utm_campaign=Feed\%3A+KluwerArbitrationBlogFull +\%28Kluwer+Arbitration+Blog+-+Latest+Entries\%29> accessed 1 March 2016.

${ }^{65}$ Camila Tomimatsu and Maríana Cattel Alves, 'The Recent Amendments to the Brazilian Arbitration Act One Step Back, Two Steps Forward?' <http://kluwerarbitrationblog.com/2015/06/30/the-recent-amendments-tothe-brazilian-arbitration-act-one-step-back-two-steps-forward/> accessed 1 March 2016.

${ }^{66}$ Decreto Legislativo 1231 por medio del cual se modificaron e incorporaron normas y disposiciones a la Ley de Arbitraje, Decreto Legislativo 1071 of 1 September 2008, 26 September 2015 <www.elperuano.com.pe/NormasElperuano/2015/09/26/1292707-1.html> accessed 1 March 2016.

${ }^{67}$ Ley 516 de promoción de inversiones, 4 April 2014 <www.lexivox.org/norms/BO-L-N516.xhtml> accessed 1 March 2016.

${ }^{68}$ Ley 20848 que establece marco para la inversión extranjera directa en Chile y crea la institucionalidad respectiva, 25 June 2015 <http://www.leychile.cl/Navegar?idNorma=1078789> accessed 1 March 2016.

69 José Luis Corvalán Pérez, 'New Rules for Foreign Investment In Chile' <http://kluwerarbitrationblog.com/2015/08/06/new-rules-for-foreign-investment-in-chile/> accessed 1 March 2016.

70 The DL 600 was repealed by Act No. 20780, Chilean Official Gazette, 29 September 2014.

71 Ley 708 de Conciliación y Arbitraje Internacional, 25 June 2015 <http://www.aduana.gob.bo/aduana7/sites/default/files/kcfinder/files/circulares/circular1322015.pdf > accessed 1 March 2016.

${ }^{72}$ Pablo Menacho Diederich, 'Conciliation and Arbitration Law: Times of Change in Investment Protection in Bolivia' <https://www.iisd.org/itn/2015/11/26/conciliation-and-arbitration-law-times-of-change-in-investmentprotection-in-bolivia/ accessed 1 March 2016.
} 
Bolivian-foreign investments or by foreign investments. After proclaiming that investment disputes are subject to the jurisdiction, laws and authorities of Bolivia (Article 127.1) and imposing compulsory conciliation as a prerequisite to gaining access to arbitration (Article 127.3), the new Act requires the resolution of investment disputes via national arbitration with seat in Bolivia (Articles 129.2 and 130.1), in which the merits of the dispute are decided by applying the Bolivian Constitution and laws (Articles 131.4 and 133.3), and establishes that the regulatory institutions and competent authorities will not see their control and supervision powers limited (Article 129.3). The real impact of this special regime needs nevertheless to be weighed against another important aspect of this Act: it prevents the use of conciliation and arbitration in subjects such as the ownership of natural resources, authorisation of the use of natural resources, access to public services, and issues dealing with public policy (orden público) (Article 4).

Another recent example of this unfavourable attitude towards the classic system of investment arbitration is the Venezuelan Act on Foreign Investments (Ley de inversiones extranjeras), enacted on 17 November $2014 .{ }^{73}$ Before that time, there was still some room for contract-based arbitration involving the Venezuelan State. ${ }^{74}$ This is no longer the case, as Article 5 of the new Act stipulates that foreign investments - which are considered of public interest (Article 3) - are subject to the jurisdiction of the Venezuelan domestic courts. At this moment, the only possible room in Venezuela for ISDS is recourse to mechanisms of dispute settlement provided for in the framework of Latin American and Caribbean integration (Article 5).

Showing an equally negative attitude towards investment arbitration, the 2015 Ecuadorian General Organic Code of Procedure (Código orgánico general de procesos $)^{75}$ has abrogated Article 42.5 of the 1997 Arbitration and Mediation Act (Ley de arbitraje $y$ mediación). ${ }^{76}$ Article 104 of this new Code creates a two-fold procedure for the recognition and enforcement of international awards: when the Ecuadorian State faces arbitral awards not dealing with commercial disputes, it has to be additionally established that the foreign award is in accordance with both the Ecuadorian Constitution and laws, and international treaties and conventions in force. ${ }^{77}$

On 11 August 2014, Mexico passed a new Hydrocarbons Act (Ley de Hidrocarburos $)^{78}$ allowing foreign direct investment in this extractive sector (Article 125) from which it has historically been excluded. On the same day, the Pemex Act (Ley de petróleos mexicanos, Ley Pemex) was also passed. ${ }^{79}$ The latter declares that before a Pemex contract is signed, all acts are of an administrative nature, whereas all the acts after contract

\footnotetext{
${ }^{73}$ Decreto 1438 con rango, valor y fuerza de Ley de inversiones extranjeras, 17 November 2014, Gaceta Oficial 6152 extraordinaria of 18 November 2014 <http://www.pgr.gob.ve/blog/wp-content/uploads/2016/02/LEY-DEINVERSIONES-EXTRANJERAS..pdf >.

${ }^{74}$ Rodrigo Polanco Lazo, 'Is there a life for Latin American Countries After Denouncing the ICSID Convention' (2014) 11 Transnational Dispute Settlement 36.

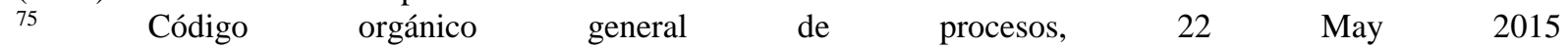
<http://www.funcionjudicial.gob.ec/pdf/CODIGO\%20ORGANICO\%20GENERAL\%20DE\%20PROCESOS.pd f> accessed 1 March 2016.

76 Ley de Arbitraje y Mediación No. 000. RO/ 145, 4 September 1997 <http://www.ftaaalca.org/busfac/comarb/Ecuador/larbymed_s.asp> accessed 1 March 2016.

${ }^{77}$ Hugo Garcia, 'The New General Organic Code of Processes: A Trojan Horse for Arbitration in Ecuador' <http://kluwerarbitrationblog.com/2015/06/24/the-new-general-organic-code-of-processes-a-trojan-horse-forarbitration-in-ecuador/> accessed 1 March 2016.

${ }^{78}$ Ley de hidrocarburos, 11 August 2014, <http://www.diputados.gob.mx/LeyesBiblio/pdf/LHidro_110814.pdf> accessed 1 March 2016.

79 Ley de petróleos mexicanos, $11 \quad$ August 2014 , <http://www.diputados.gob.mx/LeyesBiblio/pdf/LPM_110814.pdf> accessed 1 March 2016.
} 
signature have a private nature and are governed by Mexican commercial or common legislation (Article 80) ${ }^{80}$ When dealing with dispute settlement, the Pemex Act establishes a distinction between national disputes and disputes arising from acts or contracts that have effect or are executed outside Mexico. In the former case, Mexican federal courts are competent regardless of possible agreements on alternative means of dispute resolution and arbitration clauses that are compatible with the applicable corporate law and the international treaties to which Mexico is party. In the latter case, the Pemex Act may allow the application of foreign law, the jurisdiction of foreign tribunals in commercial matters, and the conclusion of arbitration agreements where appropriate to the best fulfilment of its purpose (Article 115). Dealing with the same hydrocarbons sector, Argentina passed on 30 October 2014 its Act No. 27.007, ${ }^{81}$ changing some provisions of Act No. 17.319 -Hydrocarbons Act - and adopting a more flexible approach for investments in that area.

Concerning the use of arbitration in the context of public contracts, two further contradictory trends are detected in the Latin American region. The 1997 Peruvian Public Procurement Act (Ley de contrataciones y adquisiciones del Estado $)^{82}$ made mandatory for parties to public contracts to submit their disputes to arbitration, and Article 45 of the 2014 Public Contracts Act (Ley de contrataciones del Estado) ${ }^{83}$ has added the option of referring this type of matters to dispute boards (juntas de resolución de disputas) ${ }^{84}$ On the other hand, a 2014 Colombian Presidential Directive (Directiva Presidencial en materia arbitral) ${ }^{85}$ reflects an anti-arbitration approach: the Directive requests of public servants an explicit justification before the insertion of arbitration clauses into public contracts.

\section{Conclusion}

Numerous signs predict that Latin America may play a decisive role in the worldwide design of the future investment dispute settlement system. The particular significance of the Latin American region in a new ISDS era may be derived from a plurality of factors, among which some have already been highlighted in this article. Needless to say, the multiple and very diverse approaches of Latin American countries to investment arbitration can neither be easily summarised nor should they be scrutinised under the same prism. It is true that a minority of countries took in the last decade significant actions against investment arbitration, and some

\footnotetext{
${ }^{80}$ Herfried Wöss, 'Los contratos de proyectos bajo las nuevas leyes de Pemex y CFE, así como los firmados con la CRE y la CNH, son de naturaleza mercantil' <http://energiaadebate.com/el-arbitraje-y-la-reforma-energetica/> accessed 1 March 2016.

${ }^{81}$ Ley No. 27.007 hidrocarburos, 30 October 2014, <http://www.infoleg.gob.ar/infolegInternet/anexos/235000239999/237401/norma.htm> accessed 1 March 2016.

${ }^{82}$ Ley de contrataciones y adquisiciones del Estado (Ley $\mathrm{N}^{\circ} 26850$, modificado por la Ley $\mathrm{N}^{\circ} 28267$ y su nuevo Reglamento) <http://www.oas.org/juridico/spanish/mesicic2_per_lc_nr_sp.pdf> accessed 1 March 2016. In this matter, the provisions of the 2008 Peruvian Arbitration Act (Nueva Ley peruana de arbitraje, Decreto Legislativo 1071) should also be taken into account. Franz Kundmüller Caminitin 'Obligatoriedad del arbitraje y otros temas de gestión de conflictos en la ley de contrataciones y adquisiciones del Estado y su reglamento" (1998) 39 Themis: Revista de Derecho 213; Mario Castillo Freyre and Rita Sabroso Minaya, 'Arbitraje obligatorio y de derecho en la contratación pública“ <http://www.pj.gov.py/ebook/monografias/extranjero/arbitraje/Mario-Castillo-Rita-Sabroso-Arbitraje-

Obligatorio-y-de-Derecho-en-la-Contratación-Pública.pdf> accessed 1 March 2016.

${ }^{83}$ Ley de contrataciones del Estado, Ley ${ }^{\circ}$ 30225, Diario Oficial El Peruano, 11 July 2014.

${ }^{84}$ These dispute boards are regulated in greater detail in: Reglamento de la Ley $\mathrm{N}^{\circ} 30225$, Ley de Contrataciones del Estado, $10 \quad$ December 2015 <http://portal.osce.gob.pe/osce/sites/default/files/Documentos/legislacion/ley/Reglamento\%20de\%20la\%20Ley \%20N\%\%2030225_0.pdf> accessed 1 March 2016.

85 Directiva Presidencial $\mathrm{N}^{\circ} 04$ en materia arbitral, 11 November 2014, <http://wp.presidencia.gov.co/sitios/normativa/directivas/Documents/DIRECTIVA\%20PRESIDENCIAL\%20N ${ }^{\circ}$ \%2004\%20DEL\%2011\%20DE\%20NOVIEMBRE\%20DE\%202014.pdf> accessed 1 March 2016.
} 
of these stratagems are being successful (examples include breach of condemnatory arbitral awards, propitious ex post interventions by national courts, and development of national rules impeding or restricting recourse to investor-State arbitration). Nevertheless, besides these demonstrations against the status quo, Latin America is also a land where a series of transversal and long-term initiatives with the potential to shape the future of ISDS prosper.

To the extent that common underlying themes may be discerned, two apparently contradictory elements are worth drawing attention to. First, a number of factors come presently together to draw a picture of the future of Latin America as a sub-continent where for some countries investment arbitration - if allowed - may be a mere subsidiary option in a growing number of cases. Revival of inter-State mechanisms in the settlement of disputes, both the imposition of local litigation requirements and the promotion of less-adversarial investor-State mechanisms in recent regional IIAs and national laws, and the significance of facilitation and mediation in the design of the UNASUR Centre, testify to this progressive transformation of some Latin American countries' approach to ISDS which will undoubtedly have important consequences for the region. Besides the fact that such approaches can spread - for instance Brazil's CFIA model has already served as the basis for three intra-Latin American investment treaties -, they can also have a decisive influence on key players in the new Latin American ISDS setting. States will change their strategies of participation in ISDS and future Latin American adjudicators and mediators will have a renewed profile and required qualifications. With the flourishing of regional or regionally-designed mechanisms, it is possible that Latin American professionals will play an increasingly crucial role in the ISDS system, fact which will be probably valued within the region as an illustration of its liberation from the tutelage exercised by the industrialised world.

Second, another element should equally be taken into account: the strength of local models, still to be tested, and the determination in pursuing regional solutions could influence ISDS perceptions beyond Latin America - especially if the policies pursued by some Latin American countries will not come to tarnish the credibility of these new legal instruments. For instance, in case that the UNASUR Centre for the Settlement of Investment Disputes starts to function in the near future, and supposing that its member States agree to establish a Permanent Court - if only in the fields of annulment and appeals mechanisms -, the UNASUR Centre will certainly be in the crosshairs of multiple investment treaty negotiators. Various global powers have recently started a presumably long debate about the replacement of ad hoc arbitral tribunals by a Permanent Court. In the context of a likely restructuring of the ISDS framework, the UNASUR system, whether it works efficiently or whether it reveals deficiencies, could become part of a striking worldwide precedent. 